\title{
PENGARUH KURS RUPIAH, TINGKAT SUKU BUNGA DAN TINGKAT PENGANGGURAN TERHADAP HARGA SAHAM PADA PERUSAHAAN SUB SEKTOR PERTAMBANGAN MINYAK DAN GAS BUMI YANG TERCATAT DI BURSA EFEK INDONESIA PERIODE 2012-2017
}

\author{
Atika Puspita Dewi \\ atikapuspitade@gmail.com \\ Universitas Ahmad Dahlan \\ Salamatun Asakdiyah \\ salamatun_2009@yahoo.com \\ Universitas Ahmad Dahlan
}

\begin{abstract}
ABSTRAK
The monetary situation and the movement of macroeconomic variables are things that must be considered an investor in the stock trading activity in a country. The economic situation and fluctuations in macro variables in one country can affect the stock price, including the oil and gas mining sub-sector. This study aimed to examine the effect of macroeconomic variables, namely exchange rate, interest rate, and unemployment rate to stock prices. This study uses quantitative methods. The population in this study are all oil and gas mining sub-sector companies listed in Indonesia Stock Exchange in the period 2012-2017. Sample selection technique is by using purposive sampling method. Based on predetermined criteria, acquired 7 oil and gas mining sub-sector companies sampled in this study. Data analysis techniques in this study using multiple linear regression analysis. The results showed that the variables simultaneously exchange rate, interest rate, and unemployment rate significant effect on stock price of oil and gas mining sub-sector companies. Partially, variable Exchange Rate and Interest Rate was a significant influence on stock price, while the variable Unemployment Rates no significant influence on stock price.
\end{abstract}

Keywords: Exchange Rate, Interest Rate, Unemployment Rate, Stock Price.

\begin{tabular}{l}
\hline PENDAHULUAN \\
Indonesia merupakan salah satu \\
negara yang memiliki sumber saya alam \\
yang melimpah terutama dalam sektor \\
pertambangan dan penggalian. \\
Pertambangan adalah rangkaian kegiatan \\
dalam rangka upaya pencarian, \\
penambangan (penggalian), pengolahan, \\
pemanfaatan dan penjualan bahan galian \\
(mineral, batu bara, panas bumi, migas). \\
Sektor pertambangan sekarang ini tetap \\
menjadi salah satu sektor utama yang \\
menggerakkan roda perekonomian \\
Indonesia. Untuk terus menggerakkan \\
pertumbuhan perekonomian nasional
\end{tabular}

presiden Indonesia menekankan untuk terus meningkatkan nilai ekspor dan investasi yang berperan sebagai penggerak perekonomian Indonesia. Salah satu sektor pertambangan yang berperan dalam ekspor Indonesia yaitu sektor pertambangan minyak dan gas bumi.

Minyak bumi merupakan jenis barang tambang yang sangat penting bagi stabilitas perekonomian Indonesia. Sampai sekarang, negara Indonesia masih bertumpu pada sektor migas sebagai salah satu sumber devisa negara. Hal ini sangat terlihat pada anggaran pendapatan dan belanja negara tiap tahun. Usaha penambangan minyak dan gas bumi 
dilakukan dengan sistem pengeboran, baik pengeboran darat yang dilakukan terhadap terhadap deposit minyak bumi yang mengendap pada wilayah darat, maupun pengeboran lepas pantai yang dilakukan terhadap deposit minyak bumi yang mengendap pada wilayah perairan.

Konsepsi dasar pengusahaan pertambangan migas di Indonesia adalah pasal 33 ayat 3 UUD 1945 dinyatakan "Bumi, air dan kekayan alam yang terkandung di dalamnya dikuasai oleh negara dan dipergunakan untuk sebesarbesar kemakmuran rakyat". Pasal 1 Undang-undang Nomor 22 Tahun 2001 tentang minyak dan gas bumi mendefinisikan gas dan minyak bumi adalah hasil proses alami berupa hidrokarbon yang dalam kondisi tekanan dan temperatur atmosfer berupa fasa cair atau padat, termauk aspal, lilin mineral atau ozokerit dan bitumen yang diperoleh dari proses penambangan, tetapi tidak termasuk batu bara atau endapan hidrokarbon lain yang berbentuk padat yang diperoleh oleh kegiatan yang tidak berkaitan dengan kegiatan usaha minyak dan gas bumi.

Perkembangan industri migas di Indonesia dapat dikatakan menurun dari tahun 2013 hingga 2016. Disampaikan oleh Lukman Mahfoez, Board of Director IPA (Indonesian Petroleum Association) penurunan terjadi karena mayoritas perusahaan minyak menahan diri untuk melakukan investasi akibat harga minyak dunia yang diperkirakan masih rendah. Namun seiring meningkatnya pertumbuhan ekonomi Indonesia melalui pencatatan Badan Pusat Statistik menyatakan bahwa nilai ekspor sektor minyak bumi dan gas mencapai US\$ 15.7 miliar pada tahun 2017, meningkat dibanding capaian 2016 yang sekitar US\$ 13,1 miliar. Hal ini ditopang oleh meningkatnya ekspor industri pengolahan hasilminyak sebesar $88 \%$ menjadi US\$ 1.6 miliar sedangkan pada tahun 2016 nilainya hanya US\$ 872 juta. Di sektor pertambangan minyak mentah dan gas, nilai ekspor juga tercatat meningkat $15 \%$ menjadi US\$ 14 juta dari realisasi tahun sebelumnya yang sekitar US\$12,1 juta.

Perusahaan merupakan organisasi yang mencari keuntungan sebagai tujuan utamanya walaupun tidak menutup kemungkinan mengharapkan kemakmuran sebagai tujuan utamanya. Disamping itu ada tujuan perusahaan yang tidak kalah penting yaitu dapat terus bertahan dalam persaingan, perkembang dan dapat melaksanakan fungsi-fungsi sosial lainnya di masyarakat.

Perkembangan industri juga diikuti kebutuhan dana yang besar sehingga industri harus mencari sumber dana guna melakukan operasionalnya. Kebutuhan sumber dana tersebut dapat dipenuhi dengan melakukan go publik atau menjual sahamnya kepada masyarakat melalui pasar modal. Alternatif ini merupakan alternatif yang lebih mudah dan murah jika dibandingkan sumber pendanaan lain misalnya melakukan peminjaman atau utang pada pihak lain.

Pasar modal (capital market) merupakan pasar untuk berbagai instrumen keuangan jangka panjang yang bisa diperjual belikan, baik surat utang (obligasi), ekuiti (saham), reksa dana, instrumen derivatif maupun instrumen lainnya. Pasar modal merupakan sarana pendanaan bagi perusahaan maupun institusi lain (misalnya pemerintah), dan sebagai sarana bagi kegiatan berinvestasi. Pasar modal memiliki peran penting bagi perekonomian suatu negara karena pasar modal menjalankan dua fungsi, yaitu pertama sebagai sarana bagi pendanaan usaha atau sebagai sarana bagi perusahaan untuk mendapatkan dana dari masyarakat pemodal (investor). Dana yang diperoleh dari pasar modal dapat digunakan untuk pengembangan usaha, ekspansi, penambahan modal kerja dan lain-lain, kedua pasar modal menjadi sarana bagi masyarakat untuk berinvestasi pada instrumen keuangan seperti saham, obligasi, reksa dana, dan lain-lain. Dengan demikian, masyarakat dapat menempatkan 
dana yang dimilikinya sesuai dengan karakteristik keuntungan dan risiko masing-masing instrumen.

Pasar modal yang ada di indonesia merupakan pasar yang sedang berkembang (emerging market) yang dalam perkembangannya sangat rentan terhadap kondisi makro ekonomi secara umum. Harga saham merupakan cerminan dari kegiatan pasar modal secara umum. Peningkatan harga saham menunjukkan kondisi pasar modal sedang bullish, sebaliknya jika menurun menunjukkan kondisi pasar modal sedang bearish. Untuk itu, seorang investor harus memahami pola perilaku harga saham di pasar modal. Ada beberapa teori yang dapat digunakan untu memprediksi tentang perubahan harga saham dengan kurs valuta asing dan suku bunga.

Pelaku pasar modal tentu harus mengetahui informasi penting mengenai pergerakan harga saham. Di luar arus informasi, dalam kondisi normal pergerakan saham ditentukan oleh banyak faktor, salah satunya adalah faktor fundamental. Faktor fundamental menekankan pada berita-berita yang akan mempengaruhi nilai sekuritas. Salah satu dari kelompok berita tersebut yaitu berita mengenai makro ekonomi suatu negara. Berita mengenai makro ekonomi umumnya merupakan faktor yang akan mempengaruhi keseluruhan saham yang dijual di bursa. Berita mengenai makro ekonomi suatu negar biasanya diumumkan oleh pemerintah, lembaga swadaya masyarakat ataupun lembaga internasional yang dapat mempengaruhi bursa, diantaranya adalah nilai dolar, tingkat pertumbuhan ekonomi, harga BBM, tingkat pengangguran, upah minimum regional, indeks kepercayaan konsumen dan tingkat inflasi.

Seorang investor dalam melakukan aktivitas perdagangan saham di suatu negara harus memperhatikan situasi moneter dan pergerakan variabel makro ekonomi seperti nilai tukar rupiah, tingkat suku bunga, dan tingkat pengangguran.
Keadaan ekonomi dan naik turunnya variabel makro dalam suatu negara dapat mempengaruhi harga saham, termasuk dalam sektor pertambangan. Bank Indonesia sebagai bank sentral berkewajiban melaksanakan kebijakan moneter, yaitu dengan mengontrol stabilitas perekonomian agar tidak mengalami inflasi maupun deflasi (Suparmoko, 2006).

Umumnya tingkat suku bunga yang tinggi merupakan sinyal negatif terhadap harga saham. Gujarati (2006), menjelaskan hubungan yang bersifat terbalik antara harga saham dan tingkat bunga, artinya jika tingkat bunga tinggi maka harga saham rendah, demikian pula sebaliknya. Tingkat suku bunga merupakan daya tarik bagi investor untuk menanamkan dananya dalam bentuk deposito atau SBI sehingga investasi dalam bentuk saham akan tersaingi.

Informasi lain yang harus dipertimbangkan dalam melihat harga saham adalah nilai tukar. Fluktuasi nilai tukar Rupiah yang tidak stabil dapat mengurangi tingkat kepercayaan investor. Menurut Tandelilin (2010), menguatnya nilai tukar Rupiah terhadap mata uang asing merupakan sinyal positif bagi perekonomian yang mengalami inflasi.

Mankiw (2003) mengemukakan bahwa kurs (exchange rate) antara dua negara adalah tingkat harga yang disepakati penduduk kedua negara untuk salinh melakukan perdagangan. Selain tingkat suku bunga dan nilai tukar Rupiah, tingkat pengangguran juga termasuk dalam faktor makro ekonomi yang harus diperhatikan oleh investor. Tingkat pengangguran sangat mempengaruhi ekonomi suatu negara. Semakin tinggi tingkat pengangguran, atau semakin banyak jumlah pengangguran yang ada, maka akan semakin berkurang pengeluaran konsumen yang mengakibatkan turunnya penjulan ritel. Jadi pada akhirnya, tingkat pengangguran tinggi berdampak negatif pada pertumbuhan ekonomi. 
Indikator tingkat pengangguran bisa digunakan sebagai konfirmator indikator ekonomi lainnya. Sebagai contoh, jika indikator lain menunjukkan ekspansi dan tingkat pengangguran menurun, maka pelaku bisnis akan lebih yakin untuk memulai perekrutan tenga kerja kembali. Investor akan memperhatikan statistik angka tenaga kerja untuk mellihat sektor mana yang paling cepat ditinggalkan para pekerjanya, agar bisa memutuskan untuk menjual saham-saham di sektor tersebut.

Secara umum, indikator tingkat pengangguran dan penguatan Dolar AS berkorelasi negatif. Apabila tingkat pengangguran lebih rendah dari ekspektasi, maka Dollar AS akan cenderung menguat. Karena pasar meyakini jika pengangguran yang berkurang akan mendorong penghasilan para pekerja, memacu belanja konsumen dan mendorong inflasi. Pada akhirnya, kondisi ini bisa berujung pada pertimbangan bank sentral untuk meningkatkan suku bunga. Mengingat bahwa hal-hal yang berkaitan dengan kebijakan moneter ketat relatif menunjang minat para pembeli USD, maka tak heran bila indikator tingkat pengangguran yang lebih rendah dari ekspektasi akan membantu bullish Dolar AS. Sebaliknya, hasil lebih tinggi dari prediksi cenderung membebani pergerakan Dolar AS, karena naiknya tingkat pengangguran bisa menyebabkan turunnya pendapatan, melemahnya belanja konsumen, dan melambatnya aktivitas perekonomian.

Tujuan dari penelitian ini antara lain: 1) untuk mengetahui pengaruh kurs Rupiah terhadap harga saham perusahaan sub sektor pertambangan minyak dan gas bumi yang tercatat di Bursa Efek Indonesia periode 2012-2017, 2) untuk mengetahui pengaruh tingkat suku bunga terhadap harga saham perusahaan sub sektor pertambangan minyak dan gas bumi yang tercatat di Bursa Efek Indonesia periode 2012-2017, 3) untuk mengetahui pengaruh tingkat pengangguran terhadap harga saham perusahaan sub sektor pertambangan minyak dan gas bumi yang tercatat di Bursa Efek Indonesia periode 2012-2017 dan 4) untuk mengetahui pengaruh secara simultan kurs Rupiah, tingkat suku bunga dan tingkat pengangguran terhadap harga saham perusahaan sub sektor pertambangan minyak dan gas bumi yang tercatat di Bursa Efek Indonesia periode 2012-2017.

\section{REVIEW LITERATUR DAN HIPOTESIS}

\section{Landasan Teori}

1. Pasar Modal

Menurut Husnan (2015) pasar modal adalah pasar dari berbagai instrumen keuangan (sekuritas) jangka panjang yang dapat diperjual belikan, baik dalam bentuk hutang (obligasi) maupun modal sendiri (saham) yang diterbitkan pemerintah dan perusahaan swasta.

2. Saham

Menurut Darmaji (2006) saham dapat didefinisikan sebagai tanda atau kepemilikan seseorang atau badan dalam suatu perusahaan atau perseroan terbatas.

\section{Harga Saham}

Menurut Jogiyanto (2016) harga saham adalah harga yang terjadi di pasar bursa pada saat tertentu yang ditentukan oleh pelaku pasar dan ditentukan oleh permintaan dan penawaran saham yang bersangkutan di pasar modal.

\section{Nilai Tukar}

Menurut Manurung (2009) nilai tukar adalah harga suatu mata uang dalam bentuk mata uang luar negeri.

5. Suku Bunga

Suku bunga adalah harga dari meminjam uang untuk menggunkan daya belinya (Puspopranoto, 2004). 
6. Tingkat Pengangguran

Menurut Tandelilin (2010) tingkat pengangguran ditunjukkan oleh persentase dari total jumlah tenaga kerja yang masih belum bekerja (meliputi pula pengangguran tak kentara maupun pengangguran kentara).

\section{Penelitian Terdahulu}

Ginting (2016) melakukan penelitian dengan judul Pengaruh Tingkat Suku Bunga, Nilai Tukar Dan Inflasi Terhadap Harga Saham (Studi Pada Sub-Sektor Perbankan Di Bursa Efek Indonesia Periode 2011-2015) hasil penelitian menunjukkan bahwa secara simultan variabel BI Rate, Nilai Tukar dan Inflasi berpengaruh signifikan terhadap Harga Saham Perbankan. Secara parsial, variabel BI Rate dan Inflasi tidak terdapat pengaruh yang signifikan terhadap Harga Saham, sedangkan variabel Nilai Tukar terdapat pengaruh yang signifikan terhadap Harga Saham.

Iba (2012) dalam penelitiannya yang berjudul Pengaruh Inflasi, Suku Bunga SBI, Nilai Tukar Rupiah Terhadap USD, Profitabilitas, Dan Pertumbuhan Aktiva Terhadap Harga Saham Perusahaan Pembiayaan Di Bursa Efek Indonesia (BEI). Hasil analisis linier berganda bahwa inflasi memiliki pengaruh negatif dan signifikan terhadap harga saham perusahaan pembiayaan di Bursa Efek Indonesia (BEI). Dan nilai Tukar Rupiah terhadap USD memiliki pengaruh positif dan signifikan terhadap harga saham perusahaan pembiayaan di BEI.

\section{Hipotesis}

H1: Kurs Rupiah Berpengaruh Terhadap Harga Saham.

H2: Tingkat Suku Bunga Berpengaruh Terhadap Harga Saham.
H3: Tingkat Pengangguran Berpengaruh Terhadap Harga Saham.

H4: Secara Simultan Nilai Tukar Rupiah, Tingkat Suku Bunga dan Tingkat Pengangguran Berpengaruh Terhadap Harga Saham.

\section{METODE PENELITIAN}

\section{Populasi dan Sampel}

Populasi dalam penelitian ini adalah seluruh Perusahaan Pertambangan Minyak dan Gas Bumi yang tercatat di Bursa Efek Indonesia (BEI) periode 20122017 yakni berjumlah 7 perusahaan.

Pemilihan sampel dilakukan menggunakan metode purposive sampling yang bertujuan untuk memperoleh sampel sesuai dengan kriteria-kriteria yang telah ditentukan. Kriteria yang ditetapkan yaitu perusahaan pertambangan minyak dan gas bumi yang terdaftar di Bursa Efek Indonesia Periode 2012-2017 yang menyampaikan laporan keuangannya selama periode penelitian tersebut. Hasil pemilihan menghasilkan 7 perusahaan dari populasi 7 perusahaan menyampaikan laporan keuangan selama periode 20122017.

\section{Definisi Operasional}

1. Variabel Independen

a. Nilai Tukar Rupiah

Nilai tukar yang digunakan yaitu dengan menggunakan kurs Bank Indonesia. Nilai tengah antara kurs jual dan beli yang digunakan oleh Bank Indonesia yang diterbitkan harian. Data akan diinterpolasikan menjadi data tahunan dengan satuan US\$. Data diperoleh dari websiteresmi Bank Indonesia yaitu www.bi.go.id. 
b. Tingkat Suku Bunga

Tingkat suku bunga yang digunakan yaitu BI Rate. BI Rate merupakan suku bunga kebijakan yang mencerminkan sikap atau stance kebijakan moneter yang ditetapkan oleh Bank Indonesia dan diumumkan kepada publik. Data diperoleh dari website resmi Badan Pusat Statistik yaitu www.bps.go.id yang merupakan data tahunan.

c. Tingkat Pengangguran

Tingkat pengangguran adalah presentase jumlah pengangguran terhadap jumlah angkatan kerja. Dapat dihitung menggunakan:

Tingkat Pengangguran Terbuka $=\frac{\text { Jumlah pengangguran }}{\text { Jumlah angkatan kerja }} \times 100 \%$

Satuan yang digunakan untuk tingkat pengangguran adalah presentase. Data yang didapat untuk mengukur tingkat pengangguran pada tahun 2012-2017 diambil secara langsung melalui website resmi Badan Pusat Statistik yaitu www.bps.go.id yang merupakan data per semester yang diinterpolasikan menjadi data tahunan.

\section{Variabel Dependen}

Variabel dependen dalam
penelitian ini adalah Harga Saham
pada perusahaan pertambangan minyak
dan gas bumi yang tercatat pada Bursa
Efek Indonesia. Harga saham yang
digunakan pada penelitian ini
merupakan harga penutupan setiap
akhir tahun dari perusahaan yang masuk
kepada sampel penelitian. Data harga
saham penutupan diperoleh dari website
resmi Bursa Efek Indoneisa yaitu
www.idx.co.id dan yahoo finance yaitu
finance.yahoo.com.

\section{Teknik Analisis Data}

1. Statistik Deskriptif

Statistik deskriptif memberikan gambaran atau deskriptif suatu data yang dilihat dari nilai rata-rata (mean), standar deviasi, maksimum dan minimum (Ghozali, 2013).

2. Asumsil Klasik

a. Normalitas

Uji normalitas dilakukan dengan tujuan untuk menguji apakah dalam model regresi variabel penganggu atau residual memiliki distribusi normal. Model distribusi yang baik memiliki distribusi data normal. Analisis uji normalitas melalui uji statistik Jarque-Bera. Suatu variabel dikatakan terdistribusi normal jika nilai probabilitas Jarque-Bera lebih besar dari $\alpha$ 5\% (prob. J-B > 0,05) (Kusuma, 2012).

b. Autokorelasi

Uji autokorelasi menggunaan metode Breusch-Godfrey, merupakan uji yang lebih bisa memberikan jawaban atau kepastian dari suatu analisis autokorelasi. Jika menggunakan uji DurbinWatson sebagai alat uji maka akan ada kemungkinan memberikan hasil "tidak ada kesimpulan" namun jika menggunakan uji Breusch-Godfrey tidak akan terjadi kesimpulan seperti itu (Kusuma, 2012). Berikut adalah ketentuan untuk dapat mengambil kesimpulan pada

uji Breusch-Godfrey :

Prob. Chi Square $>0,05 \rightarrow$ Tidak Terjadi Autokorelasi

Prob. Chi Square $<0,05 \rightarrow$ Terjadi Autokorelasi

Jika terjadi gejala autokorelasi maka dapat diperbaiki dengan 
melakukan respesifikasi model dengan mengguakan metode transformasi dalam bentuk invers (1/n) (Kusuma, 2012).

c. Heteroskedastisitas

Heteroskedastisitas adalah kondisi dimana nilai varians error untuk setiap data pengamatan tidak konstan. Salah satu asumsi dalam model regresi dengan OLS (Ordinary Least Square) adalah nilai error atau residual memiliki varians yang konstan atau homoskedastisitas. Adanya heteroskedastisitas ini mengakibatkan pengujian dengan uji $\mathrm{t}$ menjadi tidak valid. Terdapat beberapa metode yang dapat digunakan untuk mengidentifikasi terjadinya heteroskedastisitas salah satunya yaitu uji Breusch-PaganGodfrey (BPG). Uji BPG ini memerlukan pengurutan dan penghilangan data. Pengambilan keputusannya sebagai berikut :

Prob. Chi Square (p-value) $>0,05$ $\rightarrow$ Tidak Terjadi Heteroskedastisitas Prob. Chi Square (p-value) $<0,05$ $\rightarrow$ Terjadi Heteroskedastisitas (Kusuma, 2012).

d. Multikolinieritas

Multikolinearitas merupakan salah satu masalah dalam analisis regresi dengan OLS, yang berarti terdapat korelasi atau hubungan yang sangat tinggi pada data majemuk karena melibatkan beberapa variabel independen. Berikut adalah salah satu cara untuk penganalisaan multikolinearitas yaitu dengan pengujian korelasi. Pada pengujian ini jika korelasi antar variabel independen terlihat terlalu besar (pada umumnya $>0,90$ ) maka merupakan adanya gejala multikolinearitas (Kusuma, 2012).

3. Analisis Regresi Data Panel

Analisis regresi data panel menganalisis hubungan secara linier antara dua atau lebih variabel independen dengan variabel dependen. Analisis regresi data panel menggunakan prosedur regresi linier dengan menggunakan gabungan antara data silang (cross section) dengan data runtut waktu (times series). Pemilihan model dalam regresi ini berdasarkan:

a. Uji Chow

Uji Chow digunakan untuk mengetahui antara dua model yang akan dipilih untuk estimasi data, yaitu model Pooled Least Square (PLS) atau Fixed Effect Model (FEM) (Kusuma, 2012). Untuk mengetahui model yang digunakan yaitu sebagai berikut:

Prob. Chi Square $<0,05 \rightarrow$ Fixed Effect

Prob. Chi Square $>0,05 \rightarrow$ Common Effect

b. Uji Hausman

Uji Hausman digunakan untuk menentukan model FEM atau REM yang akan dipilih. Uji ini berdasarkan pada ide bahwa kedua metode OLS dan GLS konsisten tetapi OLS tidak efisien dalam H0 (Kusuma, 2012). Untuk mengetahui model yang digunakan yaitu sebagai berikut :

Prob. Cross section random $<0,05$

$\rightarrow$ Fixed Effect

Prob. Cross section random $>0,05$

$\rightarrow$ Random Effect 


\section{Uji Hipotesis}

1. Uji Parsial (Uji T)

Uji t pada dasarnya menujukkan seberapa jauh pengaruh satu variabel penjelas/independen secara individual dalam menerangkan variasi variabel dependen (Ghozali, 2013). Kriteria pengambilan keputusan uji t adalah:

$\mathrm{HO}$ diterima apabila $\mathrm{t}$ hitung $<\mathrm{t}$ tabel, atau signifikansi $>0.05$.

H0 ditolak apabila $\mathrm{t}$ hitung $>\mathrm{t}$ tabel, atau signifikansi $<0.05$.

2. Uji Simultan (Uji F)

Uji $F$ pada dasarnya menunjukkan apakah semua variabel bebas yang dimasukkan dalam model mempunyai pengaruh secara bersamasama terhadap variabel terikat (Ghozali, 2013). Uji ini dilakukan dengan membandingkan signifikansi $\mathrm{F}$ hitung dengan ketentuan:

1H0 diterima apabila $\mathrm{F}$ hitung $<\mathrm{F}$ tabel, atau signifikansi $>0.05$.

$\mathrm{H} 0$ ditolak apabila $\mathrm{F}$ hitung $>\mathrm{F}$ tabel, atau signifikansi $<0.05$.

3. Uji Koefisien Determinasi

Koefisien determinasi (R2) pada intinya mengukur seberapa jauh kemampuan model dalam menerangkan variasi variabel dependen (Ghozali, 2013). Nilai koefisien determinan adalah antara nol sampai satu. Nilai R2 yang kecil berarti kemampuan variabel-variabel independen dalam menjelaskan variasi variabel dependen amat terbatas. Nilai yang mendekati satu berarti variabelvariabel independen memberikan hampir semua informasi yang dibutuhkan untuk memprediksi variasi variabel dependen. Secara umum koefisien determinasi untuk data silang relatif rendah karena adanya variasi yang besar antara masing- masing pengamatan, sedangkan untuk data time series biasanya mempunyai nilai koefisien determinasi yang tinggi.

\section{HASIL PENELITIAN DAN PEMBAHASAN}

\section{Hasil Penelitian}

1. Hasil Uji Statistik Deskriptif

\begin{tabular}{|c|c|c|c|c|c|}
\hline Variabel & Mean & Median & Maximum & $\begin{array}{c}\text { Minimu } \\
\mathrm{m}\end{array}$ & Std. Dev \\
\hline $\begin{array}{c}\text { Harga } \\
\text { Saham (Y) }\end{array}$ & 281,4388 & 211,7700 & 890,0000 & 50,0000 & 221,4602 \\
\hline $\begin{array}{c}\text { Kurs } \\
\text { Rupiah } \\
\text { X1) }\end{array}$ & $12.513,00$ & $12.938,00$ & $13.795,00$ & $9.670,00$ & $1.416,948$ \\
\hline $\begin{array}{c}\text { Tingkat } \\
\text { Suku } \\
\text { Bunga (X2) }\end{array}$ & 0,062500 & 0,066250 & 0,077500 & 0,042500 & 0,014239 \\
\hline $\begin{array}{c}\text { Tingkat } \\
\text { Penganggur } \\
\text { an (X3) }\end{array}$ & 0,058400 & 0,059050 & 0,062500 & 0,054100 & 0,002899 \\
\hline
\end{tabular}

Berdasarkan hasil pengolahan data statistik pada tabel diatas yang diambil selama kurun waktu 6 tahun dari tahun 2012-2017 akan dilakukan analisis data statistik deskriptif sebagai berikut:

a. Harga Saham

Harga saham adalah satuan perubahan dimana harga berubah menurut kelipatan yang ditetapkan. Harga saham dibentuk karena adanya permintaan dan penawaran atas saham. Permintaan dan penawara atas saham tersebut terjadi karena banyak faktor, baik yang bersifat spesifik atas saham tersebut (kinerja perusahaan dan industri dimana perusahaan itu bergerak) maupun faktor makro seperti kondisi ekonomi negara, kondisi sosial maupun politik. Dari tabel di atas terlihat bahwa selama periode 20122017 harga saham memiliki nilai terendah (minimum) sebesar 50,00, sedangkan nilai tertinggi (maksimum) sebesar 890,00. Nilai rata-rata selama periode 2012-2017 
adalah sebesar 281,43, dengan standar deviasi sebesar 221,46 yang artinya bahwa nilai mean lebih besar dari pada standar deviasi, sehingga mengindikasikan bahwa hasil cukup baik. Hal tersebut dikarenakan standar deviasi adalah pencerminan penyimpangan yang sangat tinggi, sehingga penyebaran data menunjukkan hasil yang normal dan tidak menyebabkan bias.

b. Kurs Rupiah

Kurs Rupiah atau nilai tukar Rupiah adalah salah satu alat pengukur lain yang digunakan dalam menilai kekuatan suatu perekonomian. Kurs menunjukkan banyaknya uang dalam negeri yang diperlukan untuk membeli satu unit valuta asing tertentu. Dari tabel di atas terlihat bahwa selama periode 2012-2017 nilai tukar Rupiah memiliki nilai terendah (minimum) $9.670,00$, sedangkan nilai tertinggi (maksimum) sebesar 13.795,00. Nilai rata-rata selama periode 20122017 adalah sebesar 12.513,00, dengan standar deviasi sebesar 1.416,94 yang artinya bahwa nilai mean lebih besar dari pada standar deviasi, sehingga mengindikasikan bahwa hasil cukup baik. Hal tersebut dikarenakan standar deviasi adalah pencerminan penyimpangan yang sangat tinggi, sehingga penyebaran data menunjukkan hasil yang normal dan tidak menyebabkan bias.

c. Tingkat Suku Bunga

Tingkat bunga ditentukan oleh permintaan dan penawaran akan uang (ditentukan dalam pasar uang) dari masyarakat, sedangkan perubahan naik-turunnya tingkat suku bunga mempengaruhi keinginan untuk mengadakan investasi. Suku bunga adalah harga yang harus dibayar apabila terjadi pertukaran antara satu Rupiah sekarang dengan satu Rupiah nanti. Dari tabel di atas terlihat bahwa selama periode 2012-2017 tingkat suku bunga memiliki nilai terendah (minimum) sebesar 0,0425 sedangkan nilai tertinggi (maksimum) sebesar 0,0775. Nilai rata-rata selama periode 2012-2017 adalah sebesar 0,0625, dengan standar deviasi sebesar 0,0142 yang artinya bahwa nilai mean lebih besar dari pada standar deviasi, sehingga mengindikasikan bahwa hasil cukup baik. Hal tersebut dikarenakan standar deviasi adalah pencerminan penyimpangan yang sangat tinggi, sehingga penyebaran data menunjukkan hasil yang normal dan tidak menyebabkan bias.

d. Tingkat Pengangguran

Tingkat

pengangguran ditunjukkan oleh presentase dari total jumlah tenaga kerja yang masih belum bekerja (meliputi pula pengangguran tak kentara maupun pengangguran kentara). Tingkat pengangguran mencerminkan sejauh mana kapasitas operasi ekonomi suatu negara bisa dijalankan. Semakin besar tingkat pengangguran disuatu negara, berarti semakin besar kapasitas ekonomi yang belum dimanfaatkan secara penuh. Dari tabel di atas terlihat bahwa selama periode 20122017 tingkat pengangguran memiliki nilai terendah (minimum) sebesar 0,054, sedangkan nilai tertinggi (maksimum) sebesar 0,062. nilai rata-rata selama peride 20122017 adalah sebesar 0,058, dengan standar deviasi sebesar 0,002 yang artinya bahwa nilai mean lebih besar 
dari pada standar deviasi, sehingga mengindikasikan bahwa hasil cukup baik. Hal tersebut dikarenakan standar deviasi adalah pencerminan penyimpangan yang sangat tinggi, sehingga penyebaran data menunjukkan hasil yang normal dan tidak menyebabkan bias.

2. Hasil Uji Asumsi Klasik

a. Normalitas

\begin{tabular}{|l|l|l|l|l|l|}
\hline & $\begin{array}{l}\text { Harga } \\
\text { Saham }\end{array}$ & $\begin{array}{l}\text { Kurs } \\
\text { Rupiah }\end{array}$ & $\begin{array}{l}\text { Tingkat } \\
\text { Suku } \\
\text { Bunga }\end{array}$ & $\begin{array}{l}\text { Tingkat } \\
\text { Pengangguan }\end{array}$ & Residual \\
\hline $\begin{array}{l}\text { Jarque- } \\
\text { Bera }\end{array}$ & 15,309 & 9,336 & 5,373 & 2,929 & 9,732 \\
\hline Probability & 0,00047 & 0,009 & 0,068 & 0,231 & 0,0077 \\
\hline
\end{tabular}

Berdasarkan tabel di atas dapat dilihat bahwa nilai Probability J-B harga saham dan kurs rupiah sebesar $0,00047<0,05$ dan $0,009<$ 0,05 maka dapat dikatakan bahwa data tidak berdistribusi normal. Namun nilai Probability J-B tingkat suku bunga dan tingkat pengangguran sebesar 0,068>0,05 dan $0,231>0,05$ maka dapat dikatakan bahwa data berdistribusi normal.

Masalah data tidak berdistribusi secara normal dapat diperbaiki dengan melakukan penyembuhan dengan transformasi logaritma. Dapat diketahui bahwa data yang tidak berdistribusi normal adalah variabel harga saham dan kurs rupiah, namun penulis akan melakukan perbaikan pada variabel dependen yaitu variabel harga saham. Berikut ini merupakan hasil uji normalitas setelah data diperbaiki dengan transformasi logaritma sebagai berikut:

\begin{tabular}{|l|l|l|l|l|l|}
\hline & $\begin{array}{l}\text { Harga } \\
\text { Saham }\end{array}$ & $\begin{array}{l}\text { Kurs } \\
\text { Rupiah }\end{array}$ & $\begin{array}{l}\text { Tingkat } \\
\text { Suku } \\
\text { Bunga }\end{array}$ & $\begin{array}{l}\text { Tingkat } \\
\text { Pengangguan }\end{array}$ & Residual \\
\hline $\begin{array}{l}\text { Jarque- } \\
\text { Bera }\end{array}$ & 0,556 & 9,336 & 5,373 & 2,929 & 0,801 \\
\hline Probability & 0,756 & 0,009 & 0,068 & 0,231 & 0,669 \\
\hline
\end{tabular}

Berdasarkan tabel di atas dapat dilihat bahwa nilai Probability J-B harga saham setelah diperbaiki dengan log sebesar $0,756>0,05$ maka dapat dikatakan bahwa data berdistribusi normal, sedangkan nilai Probability J-B kurs rupiah tetap sebesar 0,009 $<0,05$ maka dapat dikatakan bahwa data tidak berdistribusi normal, namun demikian pengujian residual didapatkan nilai probabilitas sebesar 0,669 yang ternyata lebih besar dari $0,05(0,669>0,05)$ dengan hasil tersebut dapat disimpulkan bahwa residual persamaan regresi pada penelitian tersebut mempunyai data yang berdistribusi normal.

b. Autokorelasi

\begin{tabular}{|l|r|l|l|}
\hline \multicolumn{4}{|l|}{ Breusch-Godfrey Serial Correlation LM Test: } \\
\hline F- statistic & 9.509397 & Prob. F (2,36) & 0.0005 \\
\hline 0bs*R-square & 14.51848 & Prob. Chi-Square (2) & 0.0007 \\
\hline
\end{tabular}

Berdsarkan uji BreuschGodfrey Serial Correlation LM Test menunjukkan nilai Prob. Chi Square $<0,05$ maka dapat dikatakan bahwa data tersebut terjadi autokorelasi.

Masalah autokorelasi dapat diperbaiki dengan melakukan respesifikasi model dengan metode transformasi terhadap persamaannya (jika nilai autokorerlasi diketahui), sering disebut juga dengan Generalized Difference Equation. Transformasi dapat dilakukan dengan mengubah data dalm bentuk invers atau kuadratik. Berikut ini merupakan hasil uji autokorelasi setelah data ditransformasikan sebagai berikut: 


\begin{tabular}{|l|r|l|l|}
\hline \multicolumn{4}{|l|}{ Breusch-Godfrey Serial Correlation LM Test: } \\
\hline F- statistic & 8.853311 & Prob. F (2,36) & 0.0007 \\
\hline Obs*R-square & 13.84705 & Prob. Chi-Square (2) & 0.0010 \\
\hline
\end{tabular}

Berdasarkan uji BreuschGodfrey Serial Correlation LM Test setelah data ditransformasikan menunjukkan nilai Prob. Chi Square $<0,05$ maka dapat dikatakan bahwa data tersebut tetap terjadi autokorelasi walaupun sudah dilakukan transformasi invers.

c. Heteroskedastisitas

\begin{tabular}{|l|c|l|c|}
\hline Heteroskedasticity Test: Breusch-Pagan-Godfrey \\
\hline F- statistic & 2.714373 & Prob. F (3,38) & 0.0583 \\
\hline Obs*R-square & 7.411961 & Prob. Chi-Square (3) & 0.0599 \\
\hline Scaled explained SS & 4.097481 & Prob. Chi-Square (3) & 0.2511 \\
\hline \multicolumn{5}{|c|}{ Dari hasil pemeriksaan }
\end{tabular}
terhadap gejala heteroskedastisitas dengan uji Breusch-Pagan-Godfrey (BPG) tersebut menunjukkan nilai Prob. Chi Square pada Obs*Rsquare lebih besar dari pada 0,05 $(0,059>0,05)$. Jadi dalam data ini tidak terlihat adanya masalah heteroskedastisitas.

d. Multikolinieritas

\begin{tabular}{|c|c|c|c|}
\hline \multicolumn{4}{|c|}{ Correlation } \\
\hline & KR & TSB & TP \\
\hline KR & 1.000000 & -0.079968 & -0.724301 \\
\hline TSB & -0.079968 & 1.000000 & 0.608947 \\
\hline TP & -0.724301 & 0.608947 & 1.000000 \\
\hline
\end{tabular}

Berdasarkan

pengujian

korelasi antar variabel independen diatas tidak terlihat adanya nilai korelasi (derajat keeratan) yang sangat tinggi (> 90\%) antar variabel independen. Karena variabel independen saling berkorelasi tidak lebih dari $90 \%$ maka menunjukkan tidak adanya gejala multikolinearitas.
3. Hasil Uji Regresi Data Panel

a. Uji Chow

\begin{tabular}{|l|l|r|r|}
\hline \multicolumn{4}{|l|}{ Redundant Fixed Effect Tests } \\
\hline Pool: Untitled \\
\hline Test cross-section fixed effects \\
\hline Effect Test & Statistic & d.f. & Prob. \\
\hline Cross-section F & 6.048847 & $(6,32)$ & 0.0003 \\
\hline Cross-section Chi-square & 31.839047 & 6 & 0.0000 \\
\hline
\end{tabular}

Hasil uji chow menunjukkan bahwa nilai Prob. Chi Square sebesar 0,0000 atau lebih kecil dari 0,05. Dengan demikian dapat disimpulkan bahwa tolak H0 yang artinya model yang lebih tepat digunakan adalah model fixed effect.

b. Uji Hausman

\begin{tabular}{|c|c|c|c|}
\hline \multicolumn{4}{|c|}{ Correlated Random Effects - Hausman Test } \\
\hline \multicolumn{4}{|c|}{ Pool: Untitled } \\
\hline \multicolumn{4}{|c|}{ Test cross-section random effects } \\
\hline Test Summary & Chi-Sq. Statistic & Chi-Sq. d.f. & Prob. \\
\hline Cross-section F & 0.000000 & 3 & 1.0000 \\
\hline
\end{tabular}
Hasil uji hausman menunjukkan bahwa nilai Prob. Cross section random sebesar 1,0000 atau lebih besar dari 0,05. Dengan demikian dapat disimpulkan bahwa terima $\mathrm{HO}$ yang artinya model yang lebih tepat digunakan adalah model random effect.

c. Pemilihan Model Akhir

\begin{tabular}{|c|c|c|c|c|}
\hline \multicolumn{5}{|l|}{ Dependen } \\
\hline \multicolumn{5}{|c|}{ Method: Pooled EGLS (Cross-section random effects) } \\
\hline \multicolumn{5}{|c|}{ Sample: 20122017} \\
\hline \multicolumn{5}{|c|}{ Include observations: 6} \\
\hline \multicolumn{5}{|c|}{ Cross-section included: 7} \\
\hline \multicolumn{5}{|c|}{ Total pool (blanced) observation: 42} \\
\hline Vriable & Coefficient & Std. Error & t-Statistic & Prob. \\
\hline $\mathrm{C}$ & 13.95042 & 5.152515 & 2.707498 & 0.0101 \\
\hline KR? & -0.000290 & 0.000120 & -2.419008 & 0.0205 \\
\hline TSB? & 24.51456 & 10.38471 & 2.360640 & 0.0235 \\
\hline TP? & -111.2112 & 73.72843 & -1.508390 & 0.1397 \\
\hline \multicolumn{2}{|c|}{ R-squared } & \multicolumn{3}{|l|}{0.231506} \\
\hline \multicolumn{2}{|c|}{ Adjusted R-squared } & \multicolumn{3}{|l|}{0.170835} \\
\hline \multicolumn{2}{|c|}{ Prob(F-statistic) } & \multicolumn{3}{|l|}{0.017464} \\
\hline \multicolumn{5}{|c|}{ Berdasarkan ta } \\
\hline \multirow{2}{*}{\multicolumn{5}{|c|}{$\begin{array}{l}\text { dapat diketahui bahwa hasil } \\
\text { persamaan model estimasi adalah } \\
\text { sebagai berikut: }\end{array}$}} \\
\hline & & & & \\
\hline \multicolumn{5}{|c|}{$\mathrm{HS}=13,95042-0,000290 \mathrm{KR}+$} \\
\hline
\end{tabular}

24,51456 TSB - 111,2112 TP 
Arti angka-angka tersebut sebagai berikut: (yang diartikan adalah nilai koefisien variabel independen yang berpengaruh signifikan, yaitu nilai signifikansi kurang dari 0,05).

a. Konstanta sebesar 13,95042 artinya jika KR (kurs Rupiah), TSB (tingkat suku bunga), TP (tingkat pengangguran) nilainya adalah 0, maka besarnya $\mathrm{HS}$ (harga saham) nilainya sebesar 13,95042 .

b. Koefisien regresi variabel $\mathrm{KR}$ (kurs Rupiah) sebesar -0,0002 artinya setiap peningkatan $\mathrm{KR}$ sebesar 1 satuan, maka akan menurunkan HS (harga saham) sebesar 0,0002 satuan, dengan asumsi variabel independen lain nilainya tetap.

c. Koefisien regresi variabel TSB (tingkat suku bunga) sebesar 24,514 artinya setiap peningkatan BI Rate sebesar 1 satuan, maka akan meningkatkan HS (harga saham) sebesar 24,514 satuan, dengan asumsi variabel independen lain nilainya tetap.

d. Koefisien regresi variabel TP (tingkat pengangguran) sebesar -111,211 artinya setiap peningkatan pengangguran sebesar 1 satuan, maka akan menurunkan HS (harga saham) sebesar 111,211 satuan, dengan asumsi variabel independen lain nilainya tetap.

\section{Hasil Uji Parsial (Uji T)}

a. Variabel kurs Rupiah secara parsial berpengaruh terhadap harga saham dengan probabilitas sebesar 0,0205 . Hal tersebut menunjukkan bahwa signifikansinya $<0,05$ sehingga H0 ditolak. Jadi dapat disimpulkan bahwa kurs Rupiah memiliki pengaruh yang signifikan terhadap harga saham.

b. Variabel tingkat suku bunga berpengaruh terhadap harga saham dengan probabilitas sebesar 0,0235. Hal tersebut menunjukkan bahwa signifikansinya $<0,05$ sehingga $\mathrm{HO}$ ditolak. Jadi dapat disimpulkan bahwa tingkat suku bunga memiliki pengaruh yang signifikan terhadap harga saham.

c. Variabel tingkat pengangguran tidak berpengaruh terhadap harga saham dengan probabilitas sebesar 0,1397. Hal tersebut menunjukkan bahwa signifikansinya $>0,05$ sehingga $\mathrm{H} 0$ diterima. Jadi dapat disimpulkan bahwa tingkat pengangguran tidak memiliki pengaruh yang signifikan terhadap harga saham.

\section{Hasil Uji Simultan (Uji F)}

Variabel kurs Rupiah, tingkat suku bunga, dan tingkat pengangguran secara bersama-sama berpengaruh terhadap harga saham dengan probabilitas sebesar 0,0174. Hal tersebut menunjukkan bahwa signifikansinya $<0,05$ sehingga $\mathrm{H} 0$ ditolak, jadi dapat disimpulkan bahwa secara simultan variabel kurs Rupiah, tingkat suku bunga dan tingkat pengangguran berpengaruh terhadap harga saham pada perusahaan sub sektor pertambangan minyak dan gas bumi yang tercatat di Bursa Efek Indonesia periode 2012-2017.

\section{Hasil Uji Koefisien Determinasi}

Berdasarkan hasil yang diperoleh bahwa nilai RSquare harga saham sebesar 0,2315 hal ini berarti $23,15 \%$ variasi harga saham yang bisa dijelaskan oleh variasi dari ketiga 
variabel bebas atau independen yaitu kurs Rupiah, tingkat suku bunga dan tingkat pengangguran secara simultan. Sedangkan sisanya sebesar $100 \%$ $23,15 \%=76,85 \%$ dijelskan oleh sebab-sebab lain diluar model yang merupakan kontribusi variabel bebas lain diluar ketiga variabel independen.

\section{Pembahasan}

1. Pengaruh Kurs Rupiah terhadap Harga Saham

Kurs Rupiah berpengaruh terhadap harga saham, bahwa variabel kurs Rupiah secara simultan berpengaruh terhadap harga saham di Bursa Efek Indonesia. Karena apabila kurs Rupiah tidak terkendali maka akan menimbulkan beberapa dampak yang dapat mempengaruhi perekonomian. Beberapa akibat yang timbul dari kurs Rupiah yang tidak terkendali adalah kemerosotan pendapatan riil yang diterima oleh masyarakat, berkurangnya jumlah tabungan domestik yang merupakan sumber dana investasi bagi masyarakat negara-negara berkembang, turunnya gairah pengusaha dalam berinvestasi di pasar modal.

Dari hasil data panel diketahui bahwa kurs Rupiah yang diukur menggunakan jumlah harga saham di sektor pertambangan minyak dan gas bumi memberikan pengaruh negatif dan signifikan terhadap harga saham di Bursa Efek Indonesia dengan koefisien sebesar -2,419. Angka probabilitas signifikan pada tabel sebesar 0,0205 lebih kecil dari taraf signifikan yang digunakan yakni sebesar 0,05 yang berarti terjadi hubungan yang signifikan. Sehingga dapat disimpulkan bahwa secara parsial faktor kurs Rupiah terdapat pengaruh yang signifikan terhadap kenaikan harga saham. Jadi kenaikan kurs Rupiah menyertakan harga saham suatu perusahaan menjadi menurun.

Penelitian ini sejalan yang dilakukan oleh Ginting (2016) dalam penelitiannya dengan judul Pengaruh Tingkat Suku Bunga, Nilai Tukar Dan Inflasi Terhadap Harga Saham (Studi Pada SubSektor Perbankan Di Bursa Efek Indonesia Periode 2011-2015) secara parsial, variabel nilai tukar terdapat pengaruh yang signifikan terhadap harga saham. Hasil penelitian yang sama pun ditemukan oleh Riadi (2013) yang melakukan penelitian dengan judul Pengaruh Inflasi, Tingkat Suku Bunga Sertifikat Bank Indonesia, serta Nilai Tukar Rupiah Terhadap Jakarta Islamic Index dan Indeks LQ45. Hasil penelitian menyatakan nilai tukar rupiah berpengaruh signifikan terhadap Jakarta Islamic Index. Hasil yang sama pun ditemukan oleh Munib (2016) yang melakukan penelitian dengan judul Pengaruh Kurs Rupiah, Inflasi dan BI Rate Terhadap Harga Saham Perusahaan sektor perbankan di Bursa Efek Indonesia. Hasil menunjukkan bahwa secara parsial variabel Kurs Rupiah mempunyai pengaruh yang signifikan terhadap harga saham.

Tetapi hasil penelitian ini berbeda dengan yang dilakukan oleh Raharjo (2010) dengan judul Pengaruh Inflasi, Nilai Kurs Rupiah, dan Tingkat Suku Bunga Terhadap Harga Saham di Bursa Efek Indonesia. Metode yang digunakan yaitu metode Linier 
Berganda mengambil data dari Bursa Efek Indonesia. Memiliki hasil penelitian bahwa variabel Inflasi nilai tukar rupiah tidak memiliki pengaruh signifikan terhadap harga saham. Sedangkan hasil yang diteliti oleh Iba (2012) dalam penelitiannya Pengaruh Inflasi, Suku Bunga SBI, Nilai Tukar Rupiah Terhadap USD, Profitabilitas, Dan Pertumbuhan Aktiva Terhadap Harga Saham Perusahaan Pembiayaan Di Bursa Efek Indonesia (BEI). Hasil menunjukkan bahwa nilai tukar rupiah terhadap USD memiliki pengaruh positif dan signifikan terhadap harga saham perusahaan pembiayaan di BEI. Perbedaan ini dapat terjadi mungkin dikarenakan oleh perbedaan kurun waktu dalam penelitian dan sektor yang diteliti.

2. Pengaruh Tingkat Suku Bunga terhadap Harga Saham

Tingkat suku bunga yang tinggi merupakan sinyal negatif terhadap harga saham. Tingkat suku bunga dapat menjelaskan hubungan yang bersifat terbalik antara harga saham dan tingkat bunga, artinya jika tingkat bunga tinggi maka harga saham rendah demikian pula sebaliknya jika tingkat bunga rendah maka harga saham meningkat. Hal ini terjadi karena bila tingkat suku bunga tinggi para investor lebih tertarik menenamkan dananya dalam bentuk deposito atau SBI, sehingga investasi dalam bentuk saham tersaingi sehingga mengakibatkan harga saham menurun.

Dari hasil data panel diketahui bahwa tingkat suku bunga yang diukur menggunakan jumlah harga saham di sektor pertambangan minyak dan gas bumi memberikan pengaruh positif dan signifikan terhadap harga saham di Bursa Efek Indonesia dengan koefisien sebesar 2,360. Angka probabilitas signifikan pada tabel sebesar 0,0235 lebih kecil dari taraf signifikan yang digunakan yakni sebesar 0,05 yang berarti terjadi hubungan yang signifikan. Sehingga dapat disimpulkan bahwa secara parsial faktor tingkat suku bunga terdapat pengaruh yang signifikanterhadap kenaikan harga saham. Jadi penurunan tingkat suku bunga dari tahun ke tahun menyertakan harga saham suatu perusahaan menjadi meningkat.

Penelitian ini sejalan dengan yang dilakukan oleh Riadi (2013) yang melakukan penelitian dengan judul Pengaruh Inflasi, Tingkat Suku Bunga Sertifikat Bank Indonesia, serta Nilai Tukar Rupiah Terhadap Jakarta Islamic Index dan Indeks LQ45. Hasil penelitian menyatakan tingkat suku bunga Sertifikat Bank Indonesia berpengaruh signifikan terhadap Jakarta Islamic Index. Hasil penelitian yang sama pun ditemukan oleh Yosiana (2014) dengan judul Pengaruh BI Rate dan Kurs Rupiah Terhadap Harga Saham di Jakarta Islamic Index (JII) Tahun 20092012. Hasil menunjukkan bahwa variabel BI Rate secara uji $\mathrm{T}$ dan uji $F$ berpengaruh signifikan terhadap harga saham Jakarta Islamic Index. Hasil yang sama pun ditemukan oleh Prabowo dkk (2017) yang melakukan penelitian dengan judul pengaruh Inflasi, Tingkat Suku Bunga dan Nilai Tukar Rupiah terhadap Dolar Amerika Terhadap Harga Saham Perusahaan 
Industri Tekstil dan Garmen yang tercatat di Bursa Efek Indonesia Periode Tahun 2013-2015. Hasil penelitian menunjukkan bahwa uji secara parsial variabel Tingkat Suku Bunga memiliki pengaruh signifikan terhadap Harga Saham.

Tetapi hasil penelitian ini berbeda dengan yang dilakukan oleh Gupta (2007) yang mengadakan penelitian di Indonesia dengan judul The Causality Between Interest Rate, Exchange Rate and Stock Price in Emerging Market: The Case Of Jakarta Stock Exchange. Data yang digunakan data periode 19931997 menyimpulkan bahwa tidak ada hubungan kausalitas antara tingkat bunga dan harga saham. Begitu juga dengan hasil penelitian yang dilakukan oleh Ginting (2016) yang melakukan penelitian dengan judul Pengaruh Tingkat Suku Bunga, Nilai Tukar Dan Inflasi Terhadap Harga Saham (Studi Pada Sub-Sektor Perbankan Di Bursa Efek Indonesia Periode 2011-2015) hasil penelitian menunjukkan bahwa secara parsial, variabel BI Rate tidak terdapat pengaruh yang signifikan terhadap Harga Saham. Perbedaan ini dapat terjadi mungkin dikarenakan oleh perbedaan kurun waktu dalam penelitian dan sektor yang diteliti.

3. Pengaruh Tingkat Pengangguran terhadap Harga Saham

Pada umumnya tingkat pengangguran yang lebih rendah akan mempengaruhi Dolar Amerika yang cenderung menguat. Karena pengangguran yang berkurang akan mendorong penghasilan para pekerja sehingga memacu belanja konsumen dan mendorong inflasi.
Pada akhirnya kondisi ini berujung pada pertimbangan bank sentral untuk meningkatkan suku bunga, sehingga dengan meningkatnya suku bunga maka akan mengakibatkan penurunan harga saham, karena jika tingka suku bunga meningkat investor cenderung menanamkan dananya pada deposito atau obligasi sehingga pasar saham akan ditinggalkan yang menyebabkan harga saham menurun. Namun berbeda dengan penelitia ini yang tidak menunjukkan adanya pengaruh antara tingkat pengangguran dengan harga saham.

Dari hasil data panel diketahui bahwa tingkat pengangguran yang diukur menggunakan jumlah harga saham di sektor pertambangan minyak dan gas bumi tidak memberikan pengaruh dan tidak signifikan terhadap harga saham di Bursa Efek Indonesia dengan koefisien sebesar -1,508. Angka probabilitas signifikan pada tabel sebesar 0,1397 lebih besar dari taraf signifikan yang digunakan yakni sebesar 0,05 yang berarti tidak terjadi hubungan yang signifikan. Sehingga dapat disimpulkan bahwa secara parsial faktor tingkat pengangguran tidak terdapat pengaruh yang signifikan terhadap harga saham.

Penelitian ini sejalan dengan yang dilakukan oleh Budiman (2015) dengan judul Analisis Pengaruh Tingkat Pengangguran, Indeks Korupsi, Indeks Nikkei 225, Harga Minyak dan Harga Emas terhadap IHSG Periode 1998-2014. Hasil penelitian menunjukkan bahwa secara parsial Tingakat Pengangguran tidak berpengaruh secara signifikan terhadap IHSG. 
Tetapi hasil penelitian ini berbeda dengan yang dilakukan oleh Sirucek (2012) dengan judul Macroeconomic variabel and stock market: US review yang mengatakan bahwa faktor yang paling signifikan untuk Dow jones Industrial Average (DJIA) dan Standard and Poor's 500 (S\&P 500) indeks adalah inflasi dan tingkat pengangguran dimana keduanya memiliki pengaruh negatif (ketika IHSG naik maka pengangguran turun). Perbedaan ini dapat terjadi dikarenakan oleh perbedaan kurun waktu dalam penelitian, sektor yang diteliti, dan dikarenakan data tingkat pengangguran yang sangat berfluktuatif sehingga menunjukkan hasil penelitian yang tidak signifikan.

\section{KESIMPULAN DAN SARAN}

\section{Kesimpulan}

1. Kurs Rupiah terdapat pengaruh yang signifikan terhadap harga saham.

2. Tingkat suku bunga terdapat pengaruh yang signifikan terhadap harga saham.

3. Tingkat pengangguran tidak terdapat pengaruh yang signifikan terhadap harga saham.

4. Secara Simultan kurs Rupiah, tingkat suku bunga, dan tingkat pengangguran terdapat pengaruh yang signifikan terhadap harga saham.

\section{Saran}

1. Bagi investor disarankan untuk menggunakan faktor makro ekonomi lainnya sebagai bahan pertimbangan dalam menganalisis faktor-faktor yang mempengaruhi pergerakan harga saham.

2. Bagi peneliti selanjutnya disarankan untuk meneliti selain perusahaan sub sektor pertambangan minyak dan gas bumi dan menambah variabel yang makro ekonomi yang lebih dominan dalam peningkatan harga saham sehingga hasil yang diperoleh dalam penelitian lebih maksimal lagi.

\section{DAFTAR PUSTAKA}

Budiman, Aland Michael Aji. (2015). Analisis Pengaruh Tingkat Pengangguran, Indeks Korupsi, Indeks Nikkei 225, Harga Minyak Dan Harga Emas Terhadap IHSG Periode 1998-2014. Jurnal Parsimonia. Vol. 2 No. 1 April 2015. Universitas Ma Chung.

Darmaji dan fakhruddin. (2012). Pasar Modal di Indonesia. Edisi ketiga. Jakarta: Salemba Empat.

Ghozali, Imam. (2013). Aplikasi Analisis Multivariat dengan Program IBM SPSS 21. Edisi 7. Semarang: Penerbit Universitas Diponegoro.

Ginting, Maria Ratna Marisa, dkk. (2016). Pengaruh Tingkat Suku Bunga, Nilai Tukar Dan Inflasi Terhadap Harga Saham (Studi Pada Sub Sektor Perbankan Di Bursa Efek Indonesia Periode 2011-2015). Jurnal Administrasi Bisnis (JAB). Vol.35 No. 2 Juni 2016. Universitas Brawijaya Malang.

Gupta, J. P., Alain Chevalier dan Fran Sayekt. (2007). The Casuality Between Interest Rate, Exchange Rate And Stock Price In Emerging Markets: The Case Of The Jakarta Stock Exchange. Asian Institute of Technology, Bangkok, Thailand.

Gurajati, Damodar N. (2006). Dasardasar Ekonometrika, Jilid I. Alih Bahasa: Julius A. Mulyadi S.E. Jakarta: Erlangga. 
Husnan, Suad dan Enny Pudjiastuti. (2015). Dasar-Dasar Manajemen Keuangan. Edisi Ketujuh. Yogyakarta: UPP STIM YKPN.

Iba, Zainuddin dan Aditya Wardhana. (2012). Pengaruh Inflasi, Suku Bunga SBI, Nilai Tukar Rupiah Terhadap USD, Profitabilitas dan Pertumbuhan Aktiva Terhadap Harga Saham Perusahaan Pembiayaan Di Bursa Efek Indonesia. Jurnal Kebangsaan. Vol.1 No. 1 Januari 2012. STIE Kebangsaan Bireuen Aceh.

Jogiyanto, Hartono. (2016). Teori Portofolio dan Analisis Investasi. Edisi Kesepuluh. Yogyakarta: BPFE. Kusuma, Desta Rizky, Deny Ismanto. (2012). Modul Praktikum Eviews. Yogyakarta: FEB UAD.

Mankiw, N. Gregory. (20030 Teori Makro Ekonomi. Edisi Kelima. Terjemahan. Jakarta: Penerbit Erlangga.

Manurung, J., dan Manurung, A.H. (2009). Ekonomi Keuangan dan Kebijakan Moneter. Jakarta: Salemba Empat.

Munib, Muhammad Fatih. (2016). Pengaruh Kurs Rupiah, Inflasi Dan BI Rate Terhadap Harga Saham Perusahaan Sektor Perbankan Di Bursa Efek Indonesia. E-Journal Administrasi Bisnis. Vol. 4 No. 4 2016. Universitas Mulawarman.

Puspopranoto, Sawaldjo. (2004). Keuangan, Perbankan, dan Pasar Keuangan. Jakarta: LP3ES.

Raharjo, Sugeng. (2010). Pengaruh Inflasi, Nilai Kurs Rupiah Dan Tingkat Suku Bunga Terhadap Harga Saham Di Bursa Efek Indonesia. Jurnal Probank. Vol. 18 No. 13 November 2010. STIE AUB Surakarta.
Riadi, Ahmad., dkk. (2013). Pengaruh Tingkat Inflasi, Tingkat Suku Bunga Sertifikat Bank Indonesia, Serta Nilai Tukar Rupiah Terhadap Jakarta Islamic Index (JII) Dan Indeks LQ45. Jurnal Administrasi Bisnis. Vol. 7 No. 2. Universitas Brawijaya.

Sirucek, Martin. (2012). Macroeconomic Variables And Stock Market: US Review. MPRA Paper. No. 39094, Posted 29. Mendel University in Brno, Czech Republic.

Suparmoko, M.A, Dr. M. (2006). Ekonomi. Bogor: Quadra.

Tandelilin, Eduardus. (2010). Portofolio dan Investasi Teori dan Aplikasi. Edisi Pertama. Yogyakarta: Kanisius.

Yosiana, Yulida. (2014). Pengaruh BI Rate Dan Kurs Rupiah Terhadap Harga Saham Di Jakarta Islamic Indec (JII) Tahun 2009-2012. Skripsi. IAIN Raden Fatah Palembang.

finance.yahoo.com

www.idx.co.id

www.bi.go.id

www.bps.go 